\title{
The Family as a Cold War Weapon: Italian-American Cultural Diplomacy to Italy, 1951-1957
}

\section{Corey Cherrington ${ }^{1}$}

\begin{abstract}
Based on a full version of this project, this short paper sets out to form a descriptive analysis of Italian-American cultural diplomacy towards Italy from 1951-1957, during the Cold War era. Diverging from current scholarship on cultural diplomacy from the U.S. towards Italy in this period, I assert that intersections between gender and religion (specifically Catholicism) contributed to the ways in which Italian-Americans were able to relate with those they left behind in Italy. This paper utilizes archival evidence pertaining to Catholic Italian-Americans in Utica, New York to explore the roles of gender and religion in ItalianAmerican cultural diplomacy to Italy. The conclusion I arrive at in this project is that many Italian-Americans were not only consistently in touch with their relatives in Italy, but they also sought ardently to protect a very Catholic ideal for the family in which the woman was viewed as the protector of familial structures. In a sense, the family was used as somewhat of a strategic weapon in this cultural exchange, in an attempt to convince Italians that the wellbeing of the family rested on disavowing Communism. Moreover, this paper addresses its topic with a "one-way street"2 approach to cultural diplomacy, concentrating primarily on the historical richness of Italian-American mentalities involved in reaching out across the Atlantic to influence the politics of their ancestral homeland. As such, this essay explores Italian-American mentalities in cultural diplomacy to Italy as opposed to the effects/reception of said diplomacy in Italy.
\end{abstract}

Keywords: Cultural diplomacy, Italian-American, the family, Cold War, Catholicism

\footnotetext{
${ }^{1}$ Corey Cherrington is a recent graduate of the M.A. program for European History, Politics, and Society at Columbia University. She has published articles on European history and politics and focuses primarily on the history of foreign relations. Corey wrote the full version of this paper as a part of her participation in Columbia University's Cold War Archives Research (CWAR) Fellowship.

${ }^{2}$ Cummings, Milton C. "Cultural Diplomacy and the United States Government: A Survey." Institute for Cultural Diplomacy, 2002. http://ics.leeds.ac.uk/papers/pmt/exhibits/1434/MCCpaper.pdf, accessed May 14, 2019.
} 


\section{Introduction}

The main assertion I make in this essay is that, by analyzing the cultural diplomacy towards Italy on behalf of Italian-Americans of Utica, New York between 1951-1957, we see a focus on Catholic ideals for the family that is supported by the role of women in and relating to the family; it is concentration on the family that these Italian-Americans used to fight the Cold War in Italy. This assertion is based on research I conducted relating to interactions between gender and religion (in this case, Catholicism) within the Italian-American community of Utica, New York.

One key term used in this essay is "cultural diplomacy," which is a type of diplomacy $^{3}$ in which cultural exchanges ${ }^{4}$ and actors providing said exchanges ${ }^{5}$ are the diplomats. It has also been described as a phenomenon that can tell us more about the characteristics of different nations based on the nation's reasons and methods for using cultural diplomacy. In a sense, it represents the heart of a nation, as it is "an informal element of a nation's international relations." ${ }^{6}$ One author referred to this aspect of cultural diplomacy pointing out that “"cultural diplomacy” can also be more of a one-way street than a two-way exchange, as when one nation concentrates its efforts on promoting the national language, explaining its policies and point of view, or 'telling its story' to the rest of the world."7 Indeed, cultural diplomacy can provide valuable insights into the nation on the giving end that can enlighten better understandings of such aspects of national identity as politics, international relations, domestic culture, and others.

Most of the scholarship on cultural diplomacy going from Italian-Americans to Italy concerns itself with the 1948 "Letters to Italy" campaign, ${ }^{8}$ and, although this body of research

\footnotetext{
${ }^{3}$ Alan K. Henrikson, "Diplomacy," In Oxford Encyclopedia of the Modern World.: Oxford University Press, 2008, http://www.oxfordreference.com/view/10.1093/acref/9780195176322.001.0001/acref-9780195176322e-449.

${ }^{4}$ Victoria Phillips Geduld, "Dancing Diplomacy: Martha Graham and the Strange Commodity of Cold-War Cultural Exchange in Asia, 1955 AND 1974," Dance Chronicle 33, no. 1 (2010): 44-81, http://www.jstor.org/stable/20749313.

${ }^{5}$ Ibid.

${ }^{6}$ Barnhisel, Cold War Modernists, 12.

${ }^{7}$ Ibid.

${ }^{8}$ Examples: Wendy Wall, “America's 'Best Propagandists': Italian Americans and the 1948 'Letters to Italy' Campaign" in Appy, Christian G. ed. Cold War Constructions: The Political Culture of United States Imperialism, 1944-1966. University of MA Press, 2000; C. Edda Martinez and Edward A. Suchman, "Letters From America and the 1948 Elections in Italy," The Public Opinion Quarterly 14, no. 1 (1950): 116, http://www.jstor.org/stable/2745903; topic mentioned in Philip A. Bean, The Urban Colonists: Italian American Identity \& Politics in Utica, New York (New York: Syracuse University Press, 2010); and others.
} 
is vast, it misses some pertinent points on how gender and religion might have intersected in the campaign efforts. Other than the "Letters to Italy" campaign, there is a wealth of information that is yet untapped in this field regarding the 1950s. In this area, some scholars such as Danielle Battisti ${ }^{9}$ and Phillip Bean ${ }^{10}$ have uncovered new and important findings about Italian-Americans and the cultural cold war in Italy. Yet, even studies such as these miss many opportunities for contextualizing their work in terms of the American legacy of cultural diplomacy and could thus benefit from drawing more analytical conclusions based on gender and religion within Italian-American communities.

According to my own archival research, it appears that the promotion of Catholic family values took precedence over other factors involved in Italian-American cultural diplomacy towards Italy between 1951 and 1957, including over Italian nationalism. Although this study does not focus on all Italian-Americans, the region studied for this project was found to be representative of wider networks of Italian-Americans in the U.S. For instance, the individuals in the sample group chosen for this study were well-connected to important Italian-American groups that orchestrated such initiatives as the 1948 "Letters to Italy" campaign. More specifically, my archival evidence pertains to Our Lady of Mount Carmel Church in Utica, NY. This congregation was distinctly Italian-American and was very involved in the mission of fulfilling U.S. Cold War ambitions in Italy, focusing on Italy, Italians, and Italian-Americans in their local publications.

Of particular interest to this project are the parish bulletins from Our Lady of Mount Carmel Church in Utica, NY spanning from 1951-1956. These bulletins were published to distribute to members once a week and included a variety of announcements, from Catholic news around the world to logistics about the congregation's Mothers' Guild. ${ }^{11}$ In addition to the parish bulletins, I will discuss the charitable donations to San Pietro a Maida, Italy by an Italian-American woman from Utica, New York in $1957 .{ }^{12}$

\footnotetext{
${ }_{9}^{9}$ Danielle Battisti, Whom We Shall Welcome: Italian Americans and Immigration Reform, $1945-1965$ (New York: Fordham University Press, 2019).

${ }^{10}$ Philip A. Bean, The Urban Colonists: Italian American Identity \& Politics in Utica, New York (New York: Syracuse University Press, 2010).

${ }^{11}$ See Parish Bulletins from 1951-1954 in Box 1, Scalabrini Fathers in North America, Eastern Province, Our Lady of Mount Carmel Church, Utica, New York, Center for Migration Studies of New York, Inc.

12 Because the records of this exchange are contained in the aforementioned congregation's records, it can be assumed that this Italian-American woman was a part of Our Lady of Mount Carmel as well.
} 
Parish bulletins from 1951 indicate a strong focus on aid to Italian families, especially to orphans living in Italy at the time. One such publication from February of 1951 made a statement about "an act of Congress," which allowed "4000 Italian war orphans [to] be admitted into the U.S. extra quota, if sponsors [were] found." ${ }^{13}$ A few months later in May of 1951, another announcement was released, thanking "all those who are cooperating with the special committee in order to help unfortunate children and families of Italy."14 Yet another of this sort of announcement was made in September, when a call for resources to assist Italian refugees was issued. In this post, accommodations for "twenty-five families" was sought; in its quest for housing, the congregation sent women around "East Utica looking for apartments and found ten." 15 There is, in these announcements, an apparent focus, both at home and in regard to foreign affairs, on the family and on domestic needs being fulfilled.

Following the creation of the American Committee of Migration (ACIM) in February of 1952, Our Lady of Mount Carmel publicized the opening of a chapter of the American Committee on Italian Migration in Utica in October, 1952. ${ }^{16}$ This Committee was, according to Battisti, "the largest, most active, and politically significant Italian American organization in the 1950s and 1960s." 17 Not only was the committee run by Italian-Americans, but it was also linked strongly with the Catholic Church, with "ACIM's founding members [including] individuals already active in the NCWC [National Catholic Welfare Conference], War Relief Services (a division of the NCWC), and other Italian Americans who had been intervening in Italian recovery efforts since the war."18 Two October 1952 parish bulletins corroborate

\footnotetext{
${ }^{13}$ Parish bulletin for the week of Feb. 25, 1951, Box 1, Folder: "Church Bulletins Jan-Jun 1951," Scalabrini Fathers in North America, Eastern Province, Our Lady of Mount Carmel Church, Utica, New York, Center for Migration Studies of New York, Inc.

${ }^{14}$ Parish bulletin for the week of May 20, 1951, Box 1, Folder: "Church Bulletins Jan-Jun 1951," Scalabrini Fathers in North America, Eastern Province, Our Lady of Mount Carmel Church, Utica, New York, Center for Migration Studies of New York, Inc.

${ }^{15}$ Parish bulletin for the week of Sept. 23, 1951, Box 1, Folder: "Church Bulletins Jul-Dec 1951," Scalabrini Fathers in North America, Eastern Province, Our Lady of Mount Carmel Church, Utica, New York, Center for Migration Studies of New York, Inc.

${ }^{16}$ Parish bulletins for the weeks of October 6-12, 1952 and October 13-19, 1952, Box 1, Folder: "Church Bulletins Jul-Dec 1952," Scalabrini Fathers in North America, Eastern Province, Our Lady of Mount Carmel Church, Utica, New York, Center for Migration Studies of New York, Inc.

${ }^{17}$ Battisti, "The American Committee on Italian Migration," 12.

${ }^{18}$ Battisti, "The American Committee on Italian Migration," 18.
} 
this fact, as they state that the committee "[was] under the auspices of the Catholic Hierarchy of the United States." 19

Also according to Battisti, the ACIM of the 1950s and 1960s "[argued] that family unification, rather than racial and ethnic classifications, would serve as a more equitable and just system of governing immigration regulation," 20 which demonstrates a focus on the family within the Italian-American community. The Committee also wanted to change the perceptions of newly immigrated and assimilated Italian families in the U.S., framing them as people who "embraced American family life, consumer culture, work ethics, and educational values." 21 Thus, as the ACIM was pushing for immigration reform, they highlighted familial structures as an ideal model for improving U.S. immigration stances towards Italy. Further, the parish bulletin for the week of October 13-19, 1952 declared that "the purpose of this national organization is to solve through our Government the problem of Italy's overpopulation by sponsoring new immigration policies that will enable Italian nationals to come to this country or to migrate to the free countries of the world." ${ }^{22}$ These bulletins show a meaningful attempt on the part of Italian-Americans to both help Italy with domestic issues and to provide better lives for Italians, especially Italian families. Such an attempt to help Italy and Italians demonstrates in turn the importance that Italian-Americans placed on their roles as cultural diplomats to Italy.

1953 was a big year for Our Lady of Mt. Carmel, as it was now time for another general Italian election in which the Communist Party of Italy could take control or the Christian Democrats would continue their reign. ${ }^{23}$ The Italian general elections would take place in June of 1953, ${ }^{24}$ and the preceding months of the year would be filled with organized efforts on the part of Italian-Americans to keep communism out of Italy. This wave of efforts began for the congregation of Our Lady of Mt. Carmel in January, with a bulletin that read:

\footnotetext{
${ }_{19}$ Parish bulletins for the weeks of October 6-12, 1952 and October 13-19, 1952, Box 1, Folder: "Church Bulletins Jul-Dec 1952," Scalabrini Fathers in North America, Eastern Province, Our Lady of Mount Carmel Church, Utica, New York, Center for Migration Studies of New York, Inc.

${ }^{20}$ Battisti, "The American Committee on Italian Migration," 31.

${ }^{21}$ Battisti, "The American Committee on Italian Migration," 25-26.

22 Parish bulletin for the week of October 13-19, 1952, Box 1, Folder: "Church Bulletins Jul-Dec 1952," Scalabrini Fathers in North America, Eastern Province, Our Lady of Mount Carmel Church, Utica, New York, Center for Migration Studies of New York, Inc.

${ }^{23}$ See: Mario Del Pero, "The United States and 'Psychological Warfare' in Italy, 1948-1955," The Journal of American History 87, no. 4 (2001): 1304-1334, https://www.jstor.org/stable/2674730.

24 Del Pero, "The United States and 'Psychological Warfare' in Italy, 1948-1955," 1318. https://www.jstor.org/stable/2674730.
} 
"Urge your relatives to vote for Christian Democratic Party and against the Fascist or Communist tickets." 25 The statement here indicates a strong focus on familial ties, not emphasizing American foreign aid, but instead concentrating on "relatives" still living in Italy. By choosing to connect with relatives in 1953 as they also did in 1948, this ItalianAmerican congregation and others like it are demonstrative of the use of families as a means to participate in international Cold War battles from within the U.S.

Later in the year, just days before the election, Our Lady of Mt. Carmel produced an announcement about the 1953 general elections in Italy in which we can see a clear commitment in the congregation to defeating communism by way of communicating with "relatives and friends living in Italy."26 The repetition of "relatives and friends" later in the paragraph highlights the methods used by this Catholic Italian-American group in reaching out to family networks and other social networks across the Atlantic Ocean. They sought to utilize the bridges that were already built between the United States and Italy from a strong past of Italian migration to the United States.

Adding to this, the same parish bulletin repeated the phrase "relatives and friends" once again when referring to the preprinted letters produced by the Utica Chapter of the American Committee on Italian Migration. ${ }^{27}$ In this passage, there is also a religious charge to the call to write to friends and relatives in Italy; communism is now "Godless Communism" and thus goes directly against the core beliefs of the congregation to whom this bulletin was directed. This religious aspect of Italian-American-Italian relations in 1953 is likewise reflected in an announcement calling for support of Radio Free Europe and Asia; this request named the transnational fight against Communism a "crusade for freedom." 28 This branding of the Cold War presents the war as a religious struggle against what are referred to as the "lies" 29 of communism in which "individual citizens" have "the opportunity

\footnotetext{
25 Parish bulletin for the week of 12-18 January, 1953, Box 1, Folder: "Church Bulletins Jan-Jun, 1953," Scalabrini Fathers in North America, Eastern Province, Our Lady of Mount Carmel Church, Utica, New York, Center for Migration Studies of New York, Inc.

${ }^{26}$ Parish bulletin for the week of June 1-7, 1953, Box 1, Folder: "Church Bulletins Jan-Jun, 1953," Scalabrini Fathers in North America, Eastern Province, Our Lady of Mount Carmel Church, Utica, New York, Center for Migration Studies of New York, Inc.

${ }^{27}$ Ibid.

${ }^{28}$ Parish bulletin for the week of Feb. 23-March 1, 1953, Box 1, Folder: "Church Bulletins Jan-Jun, 1953," Scalabrini Fathers in North America, Eastern Province, Our Lady of Mount Carmel Church, Utica, New York, Center for Migration Studies of New York, Inc.

${ }^{29}$ Ibid.
} 
to strike a blow for freedom - to add our voice to the voices of Truth piercing the Iron Curtain." 30 And the specific way Italian-Americans were to do this was through connecting with relatives and friends in Italy about maintaining Catholic ideals in the journey towards a democratic and capitalist society.

With the communist threat against religion presented in this snippet is an added political element because the fact that the ACIM was involved is significant, its mission being to facilitate Italian migration to the United States and other non-communist countries, especially for Italian families. If Italy were to fall to communism after its 1953 general election, migration to the U.S. from Italy would be nearly impossible. Accordingly, there was a push in 1953 to prevent the doors between the U.S. and Italy from closing, and these Italian-Americans of Utica, NY were very much a part of this.

For Our Lady of Mt. Carmel, the years of 1954 and 1955 saw a change in tides from the 1953 elections, as after 1953, the congregation did not have Italian general elections to worry about until 1958. ${ }^{31}$ However, the congregation did not cease its emphasis on families and motherhood. For example, one 1956 post in a parish bulletin declared, "A PARTNERSHIP WITH GOD IS MOTHERHOOD. WHAT STRENGTH, WHAT PURITY, WHAT SELF-CONTROL, WHAT LOVE, WHAT WISDOM, SHOULD BELONG TO HER WHO HELPS GOD FASHION AN IMMORTAL SOUL." 32 In this instance, not only is motherhood praised, but so is the life of a child, which is described as "an immortal soul." This connects back to the "4000 Italian war orphans" that needed help in 1951 and calls attention to the prioritization of families within Italian-American communities throughout the $1950 \mathrm{~s}$.

1957 carried over this spirit of family in Italian-American interactions with Italy; here we will examine one such interaction - the charitable donations of one Italian-American woman, Elisabetta Azzarito Di Giorgio, to a poor community in Italy. Elisabetta's story is detailed in a small collection of Italian newspaper clippings that are preserved in the Center

\footnotetext{
${ }^{30}$ Ibid.

${ }^{31}$ Mattei Dogan, "Les Consequences Politiques Du Vote Feminin: Comment Les Femmes Ont Porté Les Conservateurs Au Pouvoir En Europe," International Political Science Review / Revue Internationale De Science Politique 6, no. 3 (1985): 306-16, 311, http://www.jstor.org/stable/1600700.

${ }^{32}$ Parish bulletin for the week of April 9-15, 1956, Box 1, Folder: "Church Bulletins Jan-Jun, 1956," Scalabrini Fathers in North America, Eastern Province, Our Lady of Mount Carmel Church, Utica, New York, Center for Migration Studies of New York, Inc.
} 
for Migration Studies' archive and are pasted onto form papers that read "U.S.I.S. - Italy" overhead. ${ }^{33}$ The articles found are from 1957 and showcase charitable donations organized by Elisabetta, then a resident of Utica, New York, in an Italian town, San Pietro a Maida in Calabria, Italy. ${ }^{34}$ Two of the articles state that Elisabetta was born in Italy and visited her place of birth, San Pietro a Maida, a year prior to donating clothes to children in the area in 1957. ${ }^{35}$ In this initial visit in 1956, she noticed that people living in her hometown in Italy lacked good clothing, with many of the children going barefoot. ${ }^{36}$ Upon returning to America, Elisabetta "formed a Committee of American citizens and Italian-Americans for the gathering of used clothes to send to San Pietro." 37 Elisabetta's efforts resulted in the gifting of 250 packages of clothing to children of poor families and orphans in San Pietro a Maida. ${ }^{38}$ The packages were distributed with the assistance of nuns from a Catholic church local to San Pietro a Maida, and the families of many of the children, along with "local authorities," watched as the township's children received their gifts from America. ${ }^{39}$

Among other notable details about these news articles is the fact that they not only focus on Elisabetta's identity as a woman and as an Italian-American, but also on her compliance with Catholic ideals. In particular, towards the end of these nearly identical articles is a section that discusses a "Calabrian saint, Saint San Francesco di Paola, [who] said centuries ago: 'He who has charity possesses everything. He who is without it does not have any good.' And to possess everything today is Mrs. Azzarito who, as an American, has

\footnotetext{
${ }^{33}$ Box 3, Folder: Newspaper Clippings, Gen. Corresp., Programs, Financial Statements, Newspaper Clippings, Miscellaneous Documents, Scalabrini Fathers in North America, Eastern Province, Our Lady of Mount Carmel Church, Utica, New York, Center for Migration Studies Archive. See section on U.S.I.S./U.S.I.A above.

34 "Un raggio di sole per 250 bambini," Il Mattino (First Ed.) (Naples, Italy), June 7, 1957, Scalabrini Fathers in North America, Eastern Province, Our Lady of Mount Carmel Church, Utica, New York, Box 3, Folder "Newspaper Clippings," Center for Migration Studies Archive; "Un papà Natale fuori stagione è arrivato a S. Pietro a Maida." Il Giornale (Calabria Edition) (Naples, Italy), June 6, 1957. Scalabrini Fathers in North America, Eastern Province, Our Lady of Mount Carmel Church, Utica, New York. Box 3, Folder "Newspaper Clippings." Center for Migration Studies Archive.

35 "Un papà Natale fuori stagione è arrivato a S. Pietro a Maida." Il Giornale (Calabria Edition)

36 "Un raggio di sole per 250 bambini" and "Un papà Natale fuori stagione è arrivato a S. Pietro a Maida." ${ }^{37}$ Ibid.

38 "Ai bimbi dell'Orfanotrofio di S. Pietra a Maida (Catanzaro) sono stati distribuiti, a cura di un Comitato locale, 250 pacchi vestiario raccolti da una Caomunità italo-americana di Utica (USA)." (Image). Corriere di Napoli (Noon Edition). (Naples, Italy) Scalabrini Fathers in North America, Eastern Province, Our Lady of Mount Carmel Church, Utica, New York. Box 3, Folder "Newspaper Clippings." Center for Migration Studies Archive.

39 "Un raggio di sole per 250 bambini" and "Un papà Natale fuori stagione è arrivato a S. Pietro a Maida," my translation.
} 
worked to affirm the principles of human brotherhood." ${ }^{40}$ Here, Elisabetta is portrayed as a good Christian, who can share brotherly kindness with Italy because of her sense of charity as a perceived good Catholic woman. There are two aspects of Elisabetta's story that are significant here: for one, as a woman, she focused her attention on the children in San Pietro a Maida, as opposed to the general populace. For another, Elisabetta chose to assist a town with which she had family roots and seemed to be motivated by the fact that she was born there. Family connections and ideals abound here, and this helped the U.S. in promoting its doctrine of democracy, with women as the protectors of children and family at the center, even to the farthest reaches of a small town in Southern Italy.

\section{Conclusion}

In the interactions between Italian-Americans of Our Lady of Mt. Carmel in Utica, New York and their relatives, friends, and hometowns in Italy, there is a clear, directive emphasis on the family. In the case of the parish bulletins, we see women searching for resources for needy Italian refugee families, efforts on the part of the congregation to provide for Italian orphans, and a clear concentration on the importance of familial structures. In the case of Elisabetta, we find an example of Italian-American Catholic women taking up the responsibility to protect Italian children and families from poverty and the difficulties therein. In this fight for Catholic family values is a step in the direction of utilizing American resources to influence Italy to be democratic and capitalist; in other words, by using the family as a weapon of sorts, Italian-Americans perhaps conveyed to Italians that siding with America was the way to create and/or maintain a prosperous family life in the European continent.

\section{References}

Alley, Robert S. So Help Me God: Religion and the Presidency, Wilson to Nixon. Richmond, VA: John Knox Press, 1972.

Appy, Christian G. ed. Cold War Constructions: The Political Culture of United States Imperialism, 1944-1966. University of MA Press, 2000.

${ }^{40}$ Ibid. 
Arndt, Richard T. The First Resort of Kings: American Cultural Diplomacy in the Twentieth Century. Washington, D.C.: Potomac Books, Inc., 2005.

Barnhisel, Greg. Cold War Modernists: Art, Literature, and American Cultural Diplomacy. New York: Columbia University Press, 2015.

Battisti, Danielle. "The American Committee on Italian Migration, Anti-Communism, and Immigration Reform.” Journal of American Ethnic History 31, no. 2 (2012): 11-40. doi:10.5406/jamerethnhist.31.2.0011.

- Whom We Shall Welcome: Italian Americans and Immigration Reform, 1945-1965. New York: Fordham University Press, 2019.

Bean, Philip A. The Urban Colonists: Italian American Identity \& Politics in Utica, New York. New York: Syracuse University Press, 2010.

Belmonte, Laura A. "“The Red Target is Your Home': Images of Gender and the Family." Selling the American Way: U.S. Propaganda and the Cold War. Philadelphia: University of Pennsylvania Press, 2008.

Choate, Mark I. "For Religion and for the Fatherland." Emigrant Nation: The Making of Italy Abroad. Cambridge, MA: Harvard University Press, 2008.

Costigliola, Frank and Michael J. Hogan, eds. Explaining the History of American Foreign Relations, 3rd ed. New York: Cambridge University Press, 2016.

Cummings, Milton C. "Cultural Diplomacy and the United States Government: A Survey." $\begin{array}{llll}\text { Institute } & \text { for } & \text { Cultural } & \text { Diplomacy, }\end{array}$ http://ics.leeds.ac.uk/papers/pmt/exhibits/1434/MCCpaper.pdf, accessed May 14, 2019.

De Grazia, Victoria. Irresistible Empire: America's Advance Through Twentieth-Century Europe. Cambridge, MA: Harvard University Press, 2006.

Del Pero, Mario. "American Pressures and Their Containment in Italy during the Ambassadorship of Clare Boothe Luce, 1953-1956.” Diplomatic History 28, no. 3 (2004): 407-39. http://www.jstor.org/stable/24914805.

—. "The United States and 'Psychological Warfare' in Italy, 1948-1955." The Journal of American History 87, no. 4 (2001): 1304-1334. https://www.jstor.org/stable/2674730. 
doi: 10.14267/cojourn.2020v5n1a3

Dogan, Mattei. "Les Consequences Politiques Du Vote Feminin: Comment Les Femmes Ont Porté Les Conservateurs Au Pouvoir En Europe." International Political Science Review / Revue Internationale De Science Politique 6, no. 3 (1985): 306-16. http://www.jstor.org/stable/1600700.

Ellwood, David W. "Containing Modernity, Domesticating America in Italy.” Alexander Stephan, ed. The Culture, Diplomacy and Anti-Americanism after 1945. New York: Berghahn Books, 2006.

Friedman, Andrew. Covert Capital: Landscapes of Denial and the Making of U.S. Empire in the Suburbs of Northern Virginia. Berkeley: University of California Press, 2013.

Gabaccia, Donna R. Foreign Relations: American Immigration in Global Perspective. Princeton, NJ, 2012.

Gesualdi Louis J. "Some Ideas for Italian/American Research in the Twenty-First Century." The Italian/American Experience: A Collection of Writings. New York: University Press of America, Inc., 2012.

Henrikson, Alan K. "Diplomacy." Oxford Encyclopedia of the Modern World.: Oxford University Press, 2008 http://www.oxfordreference.com/view/10.1093/acref/9780195176322.001.0001/acr ef-9780195176322-e-449.

Hogan, Michael J. The Marshall Plan: America, Britain, and the reconstruction of Western Europe, 1947-1952. Cambridge: Cambridge University Press, 1987.

Inboden, William. Religion and American Foreign Policy, 1945-1960: The Soul of Containment. Cambridge, UK: Cambridge University Press, 2008.

Kirby, Dianne. “The Religious Cold War.” In The Oxford Handbook of the Cold War: Oxford University Press, 2013-01-01. http://www.oxfordhandbooks.com/view/10.1093/oxfordhb/9780199236961.001.000 1/oxfordhb-9780199236961-e-31.

Laville, Helen. “Gender and Women's Rights in the Cold War." In The Oxford Handbook of the Cold War. Oxford University Press, 2013-01-01. https://www.oxfordhandbooks.com/view/10.1093/oxfordhb/9780199236961.001.00 01/oxfordhb-9780199236961-e-30. 
doi: 10.14267/cojourn.2020v5n1a3

Martinez, C. Edda, and Edward A. Suchman. "Letters From America and the 1948 Elections in Italy." The Public Opinion Quarterly 14, no. 1 (1950): 111-25. http://www.jstor.org/stable/2745903.

May, Elaine Tyler. Homeward Bound: American families in the Cold War era. New York: Perseus Books, 1988: 121-154.

McAndrews, Lawrence J. "Parallel Paths: Kennedy, the Church, and Nuclear War." American $\quad$ Catholic $\quad$ Studies 119, no. $1 \quad$ (2008): 1-28. http://www.jstor.org/stable/44195139.

Mistry, Kaeten. "The 1948 Election Campaign." Chapter. In The United States, Italy and the Origins of Cold War: Waging Political Warfare, 1945-1950, 127-52. Cambridge: Cambridge University Press, 2014. doi:10.1017/CBO9781139547253.007.

Moro, Renato. "The Catholic Church, Italian Catholics and Peace Movements: The Cold War Years, 1947-1962." Contemporary European History 17, no. 3 (2008): 365-90. http://www.jstor.org/stable/20081414.

Nye, Joseph. Soft Power: The Means to Success in World Politics. New York: Public Affairs Books, 2004, x.

Phillips Geduld, Victoria. "Dancing Diplomacy: Martha Graham and the Strange Commodity of Cold-War Cultural Exchange in Asia, 1955 AND 1974.” Dance Chronicle 33, no. 1 (2010): 44-81. http://www.jstor.org/stable/20749313.

Platt, Alan A., and Robert Leonardi. "American Foreign Policy and the Postwar Italian Left.” Political Science Quarterly 93, no. 2 (1978): 197-215. doi:10.2307/2148606.

Preston, Andrew. "The religious turn in diplomatic history." Costigliola, Frank and Michael J. Hogan, eds. Explaining the History of American Foreign Relations, 3rd ed. New York: Cambridge University Press, 2016.

Saunders, Frances Stonor. The Cultural War: The CIA and the World of Arts and Letters. New York: The New Press, 2000.

Serra, Ilaria. "Italy: America's War Bride. How Life Magazine Feminized Italy in the 1950s." Italica 86, no. 3 (2009): 452-70. http://www.jstor.org/stable/40505899.

Stephan, Alexander, ed. The Americanization of Europe: Culture, Diplomacy, and AntiAmericanism after 1945. New York: Berghahn Books, 2006. 
Tzu-Chun Wu, Judy. "Gendering American Foreign Relations." Costigliola, Frank and Michael J. Hogan, eds. Explaining the History of American Foreign Relations, 3rd ed. New York: Cambridge University Press, 2016.

Vuic, Kara Dixon. The Girls Next Door: Bringing the Home Front to the Front Lines. Cambridge, MA: Harvard University Press, forthcoming.

Wall, Wendy. “America's 'Best Propagandists': Italian Americans and the 1948 'Letters to Italy' Campaign.” Appy, Christian G. ed. Cold War Constructions: The Political Culture of United States Imperialism, 1944-1966. University of MA Press, 2000.

Willson, Perry. "Women's Politics in the Shadow of the Cold War, 1945-1967." Women in Twentieth-Century Italy. New York: Palgrave MacMillan, 2010. 